\title{
Fetal nutritional origins of adult diseases: challenges for epidemiological research
}

\author{
Vincent W. V. Jaddoe
}

Received: 10 November 2008/ Accepted: 10 November 2008/Published online: 29 November 2008

(C) The Author(s) 2008. This article is published with open access at Springerlink.com

\section{Introduction}

The associations of low birth weight with cardiovascular disease, type 2 diabetes and their risk factors in adult life have been studied and reviewed extensively [1]. Some reports on the early origins of adult diseases have also recently been published in the European Journal of Epidemiology [2-5]. Inverse associations between birth weight and the risk of cardiovascular disease and type 2 diabetes have been shown in different age and ethnic populations [1]. Although consistent, the overall effect size of birth weight on cardiovascular risk factors seems to be small and partially explained by compensatory postnatal growth [6-8].

The developmental origins hypothesis proposes that an increased risk of adult disease is induced by fetal adaptive responses to adverse fetal exposures, such as maternal nutritional status $[9,10]$. These adaptive responses include changes in haemodynamics, metabolism, hormone production, and tissue sensitivity and may affect development of various organs. The association between low birth weight and later disease risk should be interpreted as reflecting the long-term consequences of fetal adaptive responses. In this model, low birth weight itself is not the

\section{W. V. Jaddoe $(\bowtie)$}

The Generation R Study Group (Room AE006),

Erasmus Medical Center, P.O. Box 2040, 3000 CA Rotterdam,

The Netherlands

e-mail: v.jaddoe@erasmusmc.nl; v.jaddzxcxoe@erasmusmc.nl

\section{W. V. Jaddoe}

Department of Epidemiology, Erasmus Medical Center, Rotterdam, The Netherlands

V. W. V. Jaddoe

Department of Paediatrics, Erasmus Medical Center, Rotterdam, The Netherlands causal factor per se but merely a marker of fetal adaptive responses to suboptimal exposures. These adaptive responses are not necessarily evident at birth but may result in diseases in later life. To disentangle the mechanisms underlying the associations of low birth weight with cardiovascular disease and type 2 diabetes, various steps in the proposed pathway should be studied in more detail.

\section{Fetal nutrition}

In industrialized countries, an adverse fetal environment may be due to maternal life style habits including suboptimal dietary intake, smoking and alcohol consumption. Several historical cohort studies have studied the associations between maternal dietary intake and cardiovascular disease in adulthood [1]. Exposure to famine in fetal life and early childhood is associated with an increased risk of cardiovascular disease and type 2 diabetes [11-15]. Critical periods for exposure to famine seem to be both early fetal life and early childhood. These findings are in line with recent results from a nutritional supplementation trial in an undernourished rural population in south-India [16]. This study showed beneficial effects of balanced protein-calorie supplementation to pregnant women and preschool children on measures of insulin resistance and arterial stiffness in adolescence. These follow up results from famine exposed and severely undernourished populations are important from an etiological perspective, but are of limited use for extrapolation to contemporary children in industrialized countries. Results in normal populations showed inconsistent associations of composition of macronutrient intake in pregnant women with development risk factors for cardiovascular disease and type 2 diabetes in their offspring [17-19]. 
Rather than energy and macronutrient intake, variation in dietary patterns and micronutrient intake seem to be of more relevance in industrialized countries [20]. Observational studies showed associations of lower maternal fish intake during pregnancy with an increased risk of preterm birth and delayed developmental milestones achievement in the offspring [21-25]. Thus far, no associations with development of risk factors for cardiovascular disease and type 2 diabetes have been published. The association of fish intake with developmental milestones might be explained by direct effects on brain development. Maternal and early postnatal micronutrients related to development of cardiovascular risk factors in childhood and adulthood seem to be calcium and sodium. Prospective cohort studies showed inverse associations of maternal calcium intake with blood pressure in childhood [26-29]. However, results seem not to be consistent. Sodium intake in early infancy is associated with increased blood pressure in childhood and adulthood [30-32]. Results from animal studies showing associations between maternal iron levels and blood pressure in the offspring could not be replicated in children [33, 34]. Recent studies showed that low folate acid levels and high homocysteine levels are associated with both low birth weight and increased blood pressure in children [35-37]. Folate levels seem also to be associated with endothelial dysfunction in children, which is an early risk factor for development of atherosclerosis in adulthood [38]. Thus far, no associations of maternal intake of calcium and levels of folate and homocysteine with risk factors for cardiovascular risk factors in adults have been reported. The mechanisms by which these micronutrients influence blood pressure and the future risk of cardiovascular disease are largely unknown, but may include changes in vascular tone.

Maternal smoking and alcohol consumption during pregnancy have also been studied in relation to fetal growth and cardiovascular outcomes. Maternal smoking adversely affects fetal growth, whereas moderate alcohol consumption does not strongly increase the risk of fetal growth retardation [39-42]. Associations of maternal smoking during pregnancy with increased blood pressure in the offspring have been reported, but residual confounding cannot be excluded [43-45]. The association between maternal smoking during pregnancy and blood pressure in childhood disappeared after adjustment for paternal smoking [46]. Similar effects have recently been demonstrated for the associations of maternal smoking during pregnancy with behavioral outcomes in children [47]. These studies suggest that taking into account similar exposures in fathers in studies focused on maternal life style related habits as potential determinant enables additional adjustment for potential residual confounding.

\section{Epigenetic modifications}

Fetal nutritional exposure may lead to fetal adaptive responses by epigenetic modifications, including DNA methylation [48]. Studies in sheep showed that lower levels of maternal folate and vitamin B12 supplementation are associated with alterations in methylation status of $\mathrm{CpG}$ islands in the offspring [49]. This may influence expression of several genes. Furthermore, the offspring sheep also developed an adverse cardiovascular and metabolic phenotype. More recently, persistent impaired methylation of the IGF2 gene was reported in adults who have been exposed to the Dutch Famine [50]. These results suggest that epigenetic modifications induced by adverse nutritional exposures in the periconceptional period may persist throughout postnatal life and could affect development of risk factors for cardiovascular and type 2 diabetes. However, whether such epigenetic modifications underlie the associations between adverse fetal nutritional exposures and diseases in adult life should be studied in further detail [51]. Because the largest variation of methylation can be expected periconceptionally, important information should come from preconceptional started cohorts [52].

\section{Fetal adaptive responses}

Most studies focused on common cardiovascular risk factors in children and adults as major outcomes. However, to identify mechanisms by which fetal exposures lead to fetal adaptive responses and subsequently to increased risk of cardiovascular disease and type 2 diabetes, new methods to assess fetal growth and development in detail are necessary. Since these measurements need to be non-invasive, ultrasound or even magnetic resonance imaging should be considered. With these methods detailed studies of fetal cardiac, vascular, brain and kidney development can be performed [53-58]. We have recently shown circulatory adaptations in response to fetal growth retardation in a population-based cohort [59]. These adaptive responses were present without overt and clinically relevant fetal growth retardation. Similar effects were found on kidney growth, which tend to persist into early postnatal life [60, 61]. Detailed measurements, which are currently available in obstetric and fetal research, offer great opportunities for detailed measurements in epidemiological research. For example, with new ultrasound methods both structure and function of early and late placentation and fetal circulatory responses from first trimester onwards can be assessed [53-58]. 


\section{Conclusion}

The inverse associations between birth weight and risks of cardiovascular disease and type 2 diabetes needs further study into the underlying mechanisms. Both large-scale and more in depth epidemiological studies are needed, of which several have been described in detail in this journal [62-69]. Major efforts should be made to analyze the effects of maternal macronutrient and micronutrient intake on epigenetic modifications of specific genes related to cardiovascular development and on detailed fetal adaptive responses in early and late pregnancy. This information might lead us beyond associations of markers into real underlying causal pathways and eventually to strategies to improve public health from the earliest phase of life.

Open Access This article is distributed under the terms of the Creative Commons Attribution Noncommercial License which permits any noncommercial use, distribution, and reproduction in any medium, provided the original author(s) and source are credited.

\section{References}

1. Jaddoe VW, Witteman JC. Hypotheses on the fetal origins of adult diseases: contributions of epidemiological studies. Eur $\mathbf{J}$ Epidemiol. 2006;21:91-102. doi:10.1007/s10654-005-5924-5.

2. Silva AA, Mehta Z, O'Callaghan FJ. Duration of breast feeding and cognitive function: population based cohort study. Eur $\mathbf{J}$ Epidemiol. 2006;21:435-41. doi:10.1007/s10654-006-9018-9.

3. Vos LE, Oren A, Bots ML, Gorissen WH, Grobbee DE, Uiterwaal CS. Birth size and coronary heart disease risk score in young adulthood. The atherosclerosis risk in young adults (ARYA) study. Eur J Epidemiol. 2006;21:33-8. doi:10.1007/ s10654-005-4658-8.

4. Pollitt RA, Kaufman JS, Rose KM, Diez-Roux AV, Zeng D, Heiss G. Early-life and adult socioeconomic status and inflammatory risk markers in adulthood. Eur J Epidemiol. 2007;22:5566. doi:10.1007/s10654-006-9082-1.

5. Lawlor DA, Cooper AR, Bain C, Davey Smith G, Irwin A, Riddoch $\mathrm{C}$, et al. Associations of birth size and duration of breast feeding with cardiorespiratory fitness in childhood: findings from the Avon longitudinal study of parents and children (ALSPAC). Eur J Epidemiol. 2008;23:411-22. doi:10.1007/s10654-008-9259-x.

6. Huxley R, Neil A, Collins R. Unravelling the fetal origins hypothesis: is there really an inverse association between birthweight and subsequent blood pressure? Lancet. 2002;360:659-65. doi:10.1016/S0140-6736(02)09834-3.

7. Huxley R, Owen CG, Whincup PH, Cook DG, Colman S, Collins R. Birth weight and subsequent cholesterol levels: exploration of the "fetal origins" hypothesis. JAMA. 2004;292:2755-64. doi: 10.1001/jama.292.22.2755.

8. Tu YK, Manda SO, Ellison GT, Gilthorpe MS. Revisiting the interaction between birth weight and current body size in the foetal origins of adult disease. Eur J Epidemiol. 2007;22:565-75. doi:10.1007/s10654-007-9159-5.

9. Bateson P, Barker D, Clutton-Brock T, Deb D, D’Udine B, Foley RA, et al. Developmental plasticity and human health. Nature. 2004;430:419-21. doi:10.1038/nature02725.

10. Gluckman PD, Hanson MA, Cooper C, Thornburg KL. Effect of in utero and early-life conditions on adult health and disease. $\mathrm{N}$ Engl J Med. 2008;359:61-73. doi:10.1056/NEJMra0708473.
11. Koupil I, Shestov DB, Sparén P, Plavinskaja S, Parfenova N, Vågerö $\mathrm{D}$. Blood pressure, hypertension and mortality from circulatory disease in men and women who survived the siege of Leningrad. Eur J Epidemiol. 2007;22:223-34. doi:10.1007/ s10654-007-9113-6.

12. Sparén $P$, Vågerö D, Shestov DB, Plavinskaja S, Parfenova N, Hoptiar V, et al. Long term mortality after severe starvation during the siege of Leningrad: prospective cohort study. BMJ. 2004;328:11. doi:10.1136/bmj.37942.603970.9A.

13. Painter RC, de Rooij SR, Bossuyt PM, Simmers TA, Osmond C, Barker DJ, et al. Early onset of coronary artery disease after prenatal exposure to the Dutch famine. Am J Clin Nutr. 2006;84:322-7.

14. de Rooij SR, Painter RC, Phillips DI, Osmond C, Michels RP, Godsland IF, et al. Impaired insulin secretion after prenatal exposure to the Dutch famine. Diabetes Care. 2006;29:1897-901. doi: $10.2337 / \mathrm{dc} 06-0460$.

15. de Rooij SR, Painter RC, Roseboom TJ, Phillips DI, Osmond C, Barker DJ, et al. Glucose tolerance at age 58 and the decline of glucose tolerance in comparison with age 50 in people prenatally exposed to the Dutch famine. Diabetologia. 2006;49:637-43. doi: 10.1007/s00125-005-0136-9.

16. Kinra S, Rameshwar Sarma KV, Ghafoorunissa Mendu VV, Ravikumar R, Mohan V, Wilkinson IB, et al. Effect of integration of supplemental nutrition with public health programmes in pregnancy and early childhood on cardiovascular risk in rural Indian adolescents: long term follow-up of Hyderabad nutrition trial. BMJ. 2008;337:a605. doi:10.1136/bmj.a605.

17. Campbell DM, Hall MH, Barker DJ, Cross J, Shiell AW, Godfrey KM. Diet in pregnancy and the offspring's blood pressure 40 years later. Br J Obstet Gynaecol. 1996;103:273-80.

18. Shiell AW, Campbell-Brown M, Haselden S, Robinson S, Godfrey KM, Barker DJ. High-meat, low-carbohydrate diet in pregnancy: relation to adult blood pressure in the offspring. Hypertension. 2001;38:1282-8. doi:10.1161/hy1101.095332.

19. Huh SY, Rifas-Shiman SL, Kleinman KP, Rich-Edwards JW, Lipshultz SE, Gillman MW. Maternal protein intake is not associated with infant blood pressure. Int $\mathrm{J}$ Epidemiol. 2005;34:378-84. doi:10.1093/ije/dyh373.

20. Vujkovic M, Ocke MC, van der Spek PJ, Yazdanpanah N, Steegers EA, Steegers-Theunissen RP. Maternal western dietary patterns and the risk of developing a cleft lip with or without a cleft palate. Obstet Gynecol. 2007;110:378-84.

21. Olsen SF, Østerdal ML, Salvig JD, Kesmodel U, Henriksen TB, Hedegaard M, et al. Duration of pregnancy in relation to seafood intake during early and mid pregnancy: prospective cohort. Eur J Epidemiol. 2006;21:749-58. doi:10.1007/s10654-006-9053-6.

22. Eijsden M, Hornstra G, van der Wal MF, Vrijkotte TG, Bonsel GJ. Maternal n-3, n-6, and trans fatty acid profile early in pregnancy and term birth weight: a prospective cohort study. Am J Clin Nutr. 2008;84:887-95.

23. Hibbeln JR, Davis JM, Steer C, Emmett P, Rogers I, Williams C, et al. Maternal seafood consumption in pregnancy and neurodevelopmental outcomes in childhood (ALSPAC study): an observational cohort study. Lancet. 2007;369:578-85. doi: 10.1016/S0140-6736(07)60277-3.

24. Oken E, Østerdal ML, Gillman MW, Knudsen VK, Halldorsson TI, Strøm M, et al. Associations of maternal fish intake during pregnancy and breastfeeding duration with attainment of developmental milestones in early childhood: a study from the Danish National Birth Cohort. Am J Clin Nutr. 2008;88:789-96.

25. Oken E, Radesky JS, Wright RO, Bellinger DC, Amarasiriwardena CJ, Kleinman KP, et al. Maternal fish intake during pregnancy, blood mercury levels, and child cognition at age 3 years in a US cohort. Am J Epidemiol. 2008;167:1171-81. doi: 10.1093/aje/kwn034. 
26. Belizan JM, Villar J, Bergel E, del Pino A, Di Fulvio S, Galliano $\mathrm{SV}$, et al. Long-term effect of calcium supplementation during pregnancy on the blood pressure of offspring: follow up of a randomised controlled trial. BMJ. 1997;315:281-5.

27. Hatton DC, Harrison-Hohner J, Coste S, Reller M, McCarron D. Gestational calcium supplementation and blood pressure in the offspring. Am J Hypertens. 2003;16:801-5. doi:10.1016/S08957061(03)01027-6.

28. Gillman MW, Rifas-Shiman SL, Kleinman KP, Rich-Edwards JW, Lipshultz SE. Maternal calcium intake and offspring blood pressure. Circulation. 2004;110:1990-5. doi:10.1161/01.CIR. 0000143199.93495 .96

29. Bakker R, Rifas-Shiman SL, Kleinman KP, Lipshultz SE, Gillman MW. Maternal calcium intake during pregnancy and blood pressure in the offspring at age 3 years: a follow-up analysis of the project viva cohort. Am J Epidemiol. 2008; doi:10.1093/ aje/kwn258

30. Brion MJ, Ness AR, Davey Smith G, Emmett P, Rogers I, Whincup $\mathrm{P}$, et al. Sodium intake in infancy and blood pressure at 7 years: findings from the Avon longitudinal study of parents and children. Eur J Clin Nutr. 2008;62:1162-9. doi:10.1038/sj.ejcn. 1602837.

31. Geleijnse JM, Hofman A, Witteman JC, Hazebroek AA, Valkenburg HA, Grobbee DE. Long-term effects of neonatal sodium restriction on blood pressure. Hypertension. 1997;29:913-7.

32. Geleijnse JM, Witteman JC, Stijnen T, Kloos MW, Hofman A, Grobbee DE. Sodium and potassium intake and risk of cardiovascular events and all-cause mortality: the Rotterdam Study. Eur J Epidemiol. 2007;22:763-70. doi:10.1007/s10654-007-9186-2.

33. Belfort MB, Rifas-Shiman SL, Rich-Edwards JW, Kleinman KP, Oken E, Gillman MW. Maternal iron intake and iron status during pregnancy and child blood pressure at age 3 years. Int $\mathbf{J}$ Epidemiol. 2008;37:301-8. doi:10.1093/ije/dyn002.

34. Brion MJ, Leary SD, Smith GD, McArdle HJ, Ness AR. Maternal anemia, iron intake in pregnancy, and offspring blood pressure in the Avon longitudinal study of parents and children. Am J Clin Nutr. 2008;88:1126-33.

35. Scholl TO, Johnson WG. Folic acid: influence on the outcome of pregnancy. Am J Clin Nutr. 2000;71(Suppl(5)):1295S-303S.

36. Takimoto H, Mito N, Umegaki K, Ishiwaki A, Kusama K, Abe S, et al. Relationship between dietary folate intakes, maternal plasma total homocysteine and B-vitamins during pregnancy and fetal growth in Japan. Eur J Nutr. 2007;46:300-6. doi:10.1007/ s00394-007-0667-6.

37. Huemer M, Vonblon K, Födinger M, Krumpholz R, Hubmann M, Ulmer $\mathrm{H}$, et al. Total homocysteine, folate, and cobalamin, and their relation to genetic polymorphisms, lifestyle and body mass index in healthy children and adolescents. Pediatr Res. 2006;60:764-9. doi:10.1203/01.pdr.0000246099.39469.18.

38. Martin H, Lindblad B, Norman M. Endothelial function in newborn infants is related to folate levels and birth weight. Pediatrics. 2007;119:1152-8. doi:10.1542/peds.2006-2706.

39. Nabet C, Lelong N, Ancel PY, Saurel-Cubizolles MJ, Kaminski M. Smoking during pregnancy according to obstetric complications and parity: results of the EUROPOP study. Eur J Epidemiol. 2007;22:715-21. doi:10.1007/s10654-007-9172-8.

40. Jaddoe VW, Verburg BO, de Ridder MA, Hofman A, Mackenbach JP, Moll HA, et al. Maternal smoking and fetal growth characteristics in different periods of pregnancy: the Generation R Study. Am J Epidemiol. 2007;165:1207-15. doi:10.1093/aje/ kwm014.

41. Strandberg-Larsen K, Rod Nielsen N, Nybo Andersen AM, Olsen J, Grønbaek M. Characteristics of women who binge drink before and after they become aware of their pregnancy. Eur J Epidemiol. 2008;23:565-72. doi:10.1007/s10654-008-9265-z.
42. Jaddoe VW, Bakker R, Hofman A, Mackenbach JP, Moll HA, Steegers EA, et al. Moderate alcohol consumption during pregnancy and the risk of low birth weight and preterm birth. The Generation R Study. Ann Epidemiol. 2007;17:834-40. doi: 10.1016/j.annepidem.2007.04.001.

43. Blake KV, Gurrin LC, Evans SF, Beilin LJ, Landau LI, Stanley FJ, et al. Maternal cigarette smoking during pregnancy, low birth weight and subsequent blood pressure in early childhood. Early Hum Dev. 2000;57:137-47. doi:10.1016/S0378-3782(99) 00064-X.

44. Oken E, Huh SY, Taveras EM, Rich-Edwards JW, Gillman MW. Associations of maternal prenatal smoking with child adiposity and blood pressure. Obes Res. 2005;13:2021-8. doi: 10.1038/oby.2005.248.

45. Lawlor DA, Najman JM, Sterne J, Williams GM, Ebrahim S, Davey Smith G. Associations of parental, birth, and early life characteristics with systolic blood pressure at 5 years of age: findings from the Mater-University study of pregnancy and its outcomes. Circulation. 2004;110:2417-23. doi:10.1161/01.CIR. 0000145165.80130.B5.

46. Brion MJ, Leary SD, Smith GD, Ness AR. Similar associations of parental prenatal smoking suggest child blood pressure is not influenced by intrauterine effects. Hypertension. 2007;49:1422-8. doi:10.1161/HYPERTENSIONAHA.106.085316.

47. Roza SJ, Verhulst FC, Jaddoe VW, Steegers EA, Mackenbach JP, Hofman A, et al. Maternal smoking during pregnancy and child behaviour problems: the Generation R Study. Int $\mathrm{J}$ Epidemiol. 2008; doi:10.1093/ije/dyn163.

48. Waterland RA, Michels KB. Epigenetic epidemiology of the developmental origins hypothesis. Annu Rev Nutr. 2007;27:36388. doi:10.1146/annurev.nutr.27.061406.093705.

49. Sinclair KD, Allegrucci C, Singh R, Gardner DS, Sebastian S, Bispham J, et al. DNA methylation, insulin resistance, and blood pressure in offspring determined by maternal periconceptional B vitamin and methionine status. Proc Natl Acad Sci USA. 2007;104:19351-6. doi:10.1073/pnas.0707258104.

50. Heijmans BT, Tobi EW, Stein AD, Putter H, Blauw GJ, Susser ES, et al. Persistent epigenetic differences associated with prenatal exposure to famine in humans. Proc Natl Acad Sci USA. 2008;105:17046-9. doi:10.1073/pnas.0806560105.

51. Nafee TM, Farrell WE, Carroll WD, Fryer AA, Ismail KM. Epigenetic control of fetal gene expression. BJOG. 2008; 115:158-68. doi:10.1111/j.1471-0528.2007.01528.x.

52. Inskip HM, Godfrey KM, Robinson SM, Law CM, Barker DJ, Cooper C. Cohort profile: the Southampton women's survey. Int J Epidemiol. 2006;35:42-8. doi:10.1093/ije/dyi202.

53. Struijk PC, Mathews VJ, Loupas T, Stewart PA, Clark EB, Steegers EA, et al. Blood pressure estimation in the human fetal descending aorta. Ultrasound Obstet Gynecol. 2008;32:673-81. doi:10.1002/uog.6137.

54. Russell NE, McAuliffe FM. First-trimester fetal cardiac function. J Ultrasound Med. 2008;27:379-83.

55. de Paula CF, Ruano R, Campos JA, Zugaib M. Placental volumes measured by 3-dimensional ultrasonography in normal pregnancies from 12 to 40 weeks' gestation. J Ultrasound Med. 2008; 27:1583-90.

56. Tache V, Tarsa M, Romine L, Pretorius DH. Three-dimensional obstetric ultrasound. Semin Ultrasound CT MR. 2008;29:147-55. doi:10.1053/j.sult.2007.12.004.

57. Bardo D, Oto A. Magnetic resonance imaging for evaluation of the fetus and the placenta. Am J Perinatol. 2008;25:591-9. doi: 10.1055/s-0028-1090597.

58. Pistorius LR, Hellmann PM, Visser GH, Malinger G, Prayer D. Fetal neuroimaging: ultrasound, MRI, or both? Obstet Gynecol Surv. 2008;63:733-45. doi:10.1097/OGX.0b013e318186d3ea. 
59. Verburg BO, Jaddoe VW, Wladimiroff JW, Hofman A, Witteman JC, Steegers EA. Fetal hemodynamic adaptive changes related to intrauterine growth: the Generation R Study. Circulation. 2008;117:649-59. doi:10.1161/CIRCULATIONAHA.107.709717.

60. Verburg BO, Geelhoed JJ, Steegers EA, Hofman A, Moll HA, Witteman JC, et al. Fetal kidney volume and its association with growth and blood flow in fetal life: the Generation R Study. Kidney Int. 2007;72:754-61. doi:10.1038/sj.ki.5002420.

61. Geelhoed JJ, Verburg BO, Nauta J, Lequin M, Hofman A, Moll HA, et al. Tracking and determinants of kidney size from fetal life until the age of 2 years. The Generation R Study. Am J Kidney Disease. 2008; doi: 10.1053/j.ajkd.2008.07.030.

62. Jaddoe VW, Mackenbach JP, Moll HA, Steegers EA, Tiemeier H, Verhulst FC, et al. The Generation R Study: design and cohort profile. Eur J Epidemiol. 2006;21:475-84. doi:10.1007/s10654006-9022-0.

63. Jaddoe VW, Bakker R, van Duijn CM, van der Heijden AJ, Lindemans J, Mackenbach JP, et al. The Generation R Study biobank: a resource for epidemiological studies in children and their parents. Eur J Epidemiol. 2007;22:917-23. doi:10.1007/ s10654-007-9209-z.

64. Hofman A, Breteler MM, van Duijn CM, Krestin GP, Pols HA, Stricker BH, et al. The Rotterdam study: objectives and design update. Eur J Epidemiol. 2007;22:819-29. doi:10.1007/s10654007-9199-x.

65. Rønningen KS, Paltiel L, Meltzer HM, Nordhagen R, Lie KK, Hovengen R, et al. The biobank of the Norwegian mother and child cohort study: a resource for the next 100 years. Eur J Epidemiol. 2006;21:619-25. doi:10.1007/s10654-006-9041-x.

66. Gravseth HM, Bjerkedal T, Irgens LM, Aalen OO, Selmer R, Kristensen P. Life course determinants for early disability pension: a follow-up of Norwegian men and women born 19671976. Eur J Epidemiol. 2007;22:533-43. doi:10.1007/s10654007-9139-9.

67. Raynor P. Born in Bradford Collaborative Group. Born in Bradford, a cohort study of babies born in Bradford, and their parents: protocol for the recruitment phase. BMC Public Health. 2008;8:327. doi:10.1186/1471-2458-8-327.

68. Clarisse B, Nikasinovic L, Poinsard R, Just J, Momas I. The Paris prospective birth cohort study: which design and who participates? Eur J Epidemiol. 2007;22:203-10. doi:10.1007/s10654007-9109-2.

69. Richiardi L, Baussano I, Vizzini L, Douwes J, Pearce N, Merletti F. NINFEA cohort. Feasibility of recruiting a birth cohort through the internet: the experience of the NINFEA cohort. Eur J Epidemiol. 2007;22:831-7. 23. 